\title{
Introduction: the evolution of intergovernmental financial relations in the twenty-first century
}

\section{Richard Eccleston, Rob Hortle and Richard Krever}

\section{AIMS OF THE STUDY}

The first decade and a half of the twenty-first century can be characterized as a period of economic and political instability and change. The financial crisis and its aftermath that has disrupted global markets since 2008 is perhaps the most significant international political and economic development over this period. The acute impact of the 'Great Recession' has generated a good deal of scholarship on both the short-term international policy response to the crisis as well as the subsequent sovereign debt and budgetary challenges that emerged as governments embarked on the long and fiercely contested process of fiscal consolidation and budget repair. With the passage of time, more attention is being paid to the subtle, yet significant processes through which crisis-related pressures are being mediated by pre-existing domestic political interests, issues and institutional structures. ${ }^{1}$ Such historically grounded accounts enhance our understanding of the complex processes that are reshaping twenty-first-century politics (Grant and Wilson 2012; Moschella and Tsingou 2013; Helleiner 2014; Bell and Hindmoor 2015).

There is mounting evidence that a broad array of political and economic pressures - some linked to the crisis and its legacies, others not - are having a profound influence on key political and economic settlements established in the late twentieth century. Analysts and activists anticipating radical post-crisis reform may have been disappointed but, as the increasingly sophisticated literature on institutional change and dynamics highlights, crisis-induced change is often contested and incremental, yielding new political orders and practices over the longer term (Pierson 2004; Streeck and Thelen 2005; Mahoney and Thelen 2010). Hence, the likely consequences of crises such as that which engulfed the world economy in 2008-9 only become evident once the dust begins to settle and their impact 
on deeply institutionalized economic interests, political orders and ideas becomes apparent. An equally plausible scenario is that crisis-induced change may amount to no more than a disruption in the longer term and sustained institutional change will be driven by factors that either preceded or are independent of the crisis (Campbell 2004; Oliver and Pemberton 2004). Clearly any credible analysis of emerging trends in twenty-firstcentury political practice must be cognizant of the crisis and its consequences while remaining mindful of the fact that this is one among many factors influencing political change. The causes of institutional change may be both contested and complex but there is a consensus that the nature of change varies both across policy arenas and between jurisdictions, highlighting the need to present fine-grained comparative analysis.

Contemporary institutional change has many dimensions and this study is particularly concerned with documenting recent developments and analysing emerging trends in the fiscal element of federal governance. We are particularly interested in changing patterns of intergovernmental financial relations and their implications for the future of federalism. Our focus on the future of federalism in the twenty-first century is significant, because despite the increasingly ubiquitous nature of devolution and multilevel governance regimes in the early years of this century, there is relatively little research on contemporary trends in intergovernmental relations and their consequences. Such scholarship is important given tensions and, in some cases, contradictions in the extant federalism literature (discussed in greater detail in Chapter 1). Scholarship in the public choice tradition suggests that federal regimes are particularly vulnerable to the political, economic and fiscal consequences of economic crises, while other scholars from schools more concerned with institutional foundations of political regimes have argued that constitutionally entrenched federal orders provide a source of stability during such periods of upheaval (Wibbels 2000; Simeon and Conway 2001; Erk and Swenden 2010). Similarly, while much of the literature on comparative federalism suggests that federal relations are deeply institutionalized and are highly path dependent once a specific political settlement has been brokered (Scharpf 1988; Bednar 2011), there is contemporary scholarship that highlights the potential role of changing societal pressures in reshaping federal relations and the practice of intergovernmental politics (Erk 2008; Colino 2010; Colino and del Pino 2014). In sum, there are a number of theoretical and empirical questions to be answered by way of systematic research exploring patterns of contemporary change and associated trends in federal systems.

The majority of the world's most powerful states are federations of various hues, all facing different governance and fiscal challenges. If, as in this volume, a broad definition of federalism is adopted so as to include 
'federalizing' jurisdictions such as China and the United Kingdom, then 15 members of the G20 - including the four 'BRIC' (Brazil, Russia, India and China) economies - are federal or quasi-federal states. ${ }^{2}$ Moreover, approximately 40 per cent of the global population lives in federal jurisdictions (Kincaid et al. 2010, p.6).

The trend towards devolution and multilevel governance may be a significant feature of early twenty-first-century political practice, but federalism is not without its critics. Indeed a strong theme in the seminal literature on fiscal federalism in the 1960s and 1970s was that economic coordination and debt management in federal systems both complicates policy responses to economic crises and undermines their effectiveness (Olson 1965; Oates 1972). If this is true, perceived shortcomings in intergovernmental relations in the context of the 2008 financial crisis may serve as a catalyst for reforming federations and adopting more centralized governance structures. Beyond debates about crisis management (discussed in greater detail in Chapter 1, section 1.4), there is a rich literature on federalism and the welfare state both as a laboratory for policy development and the centralizing influence (and associated growth in intergovernmental apparatus) associated with the growth of the post-war welfare state in most federal systems (Obinger et al. 2005). While significant contributions to the literature suggest entrenched federal orders may act as a foil against welfare state retrenchment, such claims have not been tested in the current environment of fiscal consolidation and budget repair.

A phenomenon observable in many federal systems in the post-crisis era is heightened intergovernmental conflict over the distribution of fiscal resources or expenditure responsibilities. Such distributional tensions can have either vertical (between central governments and subnational governments) or horizontal (between subnational governments) dimensions and may undermine and transform federal orders. For example, Braun and Trein $(2014$, p. 806) highlight the potential for both increased centralization (vertical control) and 'de-solidarization' (horizontal conflict) in federal regimes in the aftermath of a financial crisis. While undoubtedly reflecting the impacts of prevailing economic conditions, federal settlements are also shaped by a broader constellation of societal factors, including prevailing norms, cultural and linguistic cleavages, policy frameworks and patterns of interest representation such as prevailing party systems (Erk 2008; Colino 2014). Moreover, the significant political consequences of the financial crisis in many jurisdictions, particularly in southern Europe, have the potential to disrupt the societal basis of federal orders, phenomena that the case studies in this volume will document and analyse. The aim is to investigate more closely through actual examples the ways in which the political and economic developments that have defined the formative years 
of the twenty-first century may transform the practice of federalism (Benz and Broschek 2013).

Federalism, with all of its strengths, shortcomings and potential vulnerabilities, remains one of the most significant forms of political organization in the early twenty-first century. Yet remarkably there is a paucity of detailed comparative research on the longer-term political and economic trends in federal systems. As Braun and Trein (2014, p. 804) observe in an important preliminary contribution to this literature: 'The link between an economic and/or financial crisis and the dynamics of federal relations has, to the best of our knowledge, not been treated on a comparative basis.' This volume addresses this critical gap in the literature through the provision of a systematic account of the medium and likely longer-term forces shaping the practice of federalism and intergovernmental relations in the early twenty-first century.

In summary the book has the following aims:

1. To identify the key forces reshaping federal relations in the early twenty-first century across a diverse range of federal states. Fiscal variables including financial vulnerability and conflict over budget resources may be central to changes in some cases but consideration will also be given to a broader range of socio-political developments.

2. To document the emerging political implications of the forces noted above on federal dynamics and the associated prospects for change at either the level of informal federal relations or formal federal settlements.

3. To analyse similarities and differences across the cases and reflect on the implications of this case data for extant and emerging theories of federal dynamics.

\section{RESEARCH DESIGN}

At the broadest level this volume will enhance our understanding of emerging trends in federal governance and their theoretical and practical implications. Reflecting the diversity of federal systems and practices, the book will adopt an inductive case study method that draws on recent innovations in institutional theory to generate strategic comparisons among 12 significant federal jurisdictions. This methodology, discussed in greater detail in Chapter 1, reflects a growing acceptance of the sui generis problem among scholars of comparative federalism: in any historical context there are too many cultural, economic, geographic and political variables across a relatively finite number of cases to formulate and test formal hypotheses 
Table I.1 The Future of Federalism: case studies

\begin{tabular}{ll}
\hline Case & Author(s) \\
\hline United States (Chapter 2) & Paul L. Posner and Timothy J. Conlan \\
Canada (Chapter 3) & Douglas M. Brown \\
Australia (Chapter 4) & Richard Eccleston and Richard Krever \\
United Kingdom (Chapter 5) & Simon Lee \\
Germany (Chapter 6) & Jan Schnellenbach \\
Switzerland (Chapter 7) & Nils Soguel \\
Spain (Chapter 8) & César Colino and Eloísa del Pino \\
Italy (Chapter 9) & Emanuele Massetti \\
China (Chapter 10) & Christine Wong \\
India (Chapter 11) & Raghbendra Jha \\
Brazil (Chapter 12) & José Roberto Afonso and Luiz de Mello \\
South Africa (Chapter 13) & Ramos Mabugu \\
\hline
\end{tabular}

regarding the impact of federal relations on political outcomes, or how and why federal systems themselves change over time. As Colino (2014, p. 50) argues, many typologies of federal systems have merit yet 'cannot reflect or predict the functioning or evolution of federations, leaving many federations outside their scope'.

Given this diversity, the study presents a detailed account of 12 significant cases selected to represent the full range of federal and quasi-federal governance structures, in what Gerring and McDermott (2007, p. 89) describe as a 'diverse' case selection (Table I.1). Reflecting this approach, the study includes: (1) mature, high-income federations that were hard hit by the crisis and its aftermath; and (2) large emerging federations such as Brazil, India and China, where the immediate impact of the crisis was less acute but where the deferred impact is now being felt, sometimes very significantly. The inclusion of both established and emerging federations means that all bar two of the selected case studies are members of the G20 and thus can claim to be among the most important and economically powerful federal regimes. Through the systematic analysis of these significant yet diverse cases the book seeks to identify and analyse the key trends that are emerging in contemporary federal governance. While this historically grounded approach is not intended to test hypotheses in a formal sense, the empirical analysis presented is designed to generate theoretical claims and draw inferences that will enhance our understanding of the ways in which federal systems are changing, as well as the broader implications of these developments for political practice (King et al. 1994, ch. 2). If nothing else, the study can reveal the ways in which different federal systems can adapt to changed economic and fiscal environments. 
To capture these complex and distinctive dynamics and the ways in which variations in 'federal regimes' and domestic economic and political circumstances are influencing the future of federalism in each of our case studies, this book brings together contributions from established country specialists. All the contributors possess deep expertise and an appreciation of the manner in which domestic variables have mediated the impact of the crisis and its aftermath on the practice of federalism in their respective jurisdictions. To ensure that the work is much more than a disparate collection of national studies, the contributors to this collection have specifically engaged with the research agenda outlined below in an attempt to draw systematic conclusions regarding the longer-term impact of the 2008 financial crisis on the practice of federalism in the twenty-first century. The coherence of the analysis presented in subsequent pages has been enhanced by a workshop at which contributors presented draft chapters and identified common analytical themes and empirical patterns.

Reflecting the ambitions of this volume, each of the case studies that follows takes the form of what Kay (2006, p. 1) calls a 'structured narrative' that 'seeks to make sense of events and render them intelligible through use of some greater interpretive scheme' (Eccleston 2007, p. 32; Hay 2002, p.47). Structured narratives differ from descriptive accounts in that they map the interaction between multiple variables, which the extant literature suggests may contribute to institutional change. In this sense, each of the case studies engages with contemporary theories of institutional change generally and the literature on federal dynamics in particular (which is summarized in Chapter 1), although determining the specific processes that lead to policy change in any given case study - and the relationship between them - remains an empirical question. Analysis of similarity and difference in the dynamics of change across the 12 cases and the extent to which these provide a foundation for theoretical claims about such processes is the focus of the concluding chapter.

In line with this approach, each of the case study chapters begins with an overview of the history and structure of the federal system in the jurisdiction, emphasizing financial elements. It is necessary to highlight pre-crisis issues and tensions in the intergovernmental system to establish whether or not the financial crisis of 2008-9 represented a critical juncture or whether contemporary developments are more evolutionary in nature and shaped by long-term adaptation and feedback. Contributors build on existing scholarship on 'crisis federalism' and present a brief summary of the intergovernmental dimension of the crisis response in each of the cases before reflecting on whether these dynamics have been sustained during the subsequent period of fiscal consolidation and budget repair the so-called 'second phase' of the crisis. This analysis focuses on the fiscal 
dimension of federal relations since 2010 with an emphasis on the distribution of the 'burden of austerity', both vertically between the central government and subnational governments and horizontally among subnational governments. Both existing macroeconomic data on the severity of the crisis as well as data on the relative fiscal pressures facing central and subnational governments are incorporated into the case studies (presented in Chapter 1).

Following this empirical sketch of the impact of the crisis on intergovernmental relations across the cases, the main focus of the empirical chapters is an assessment of the longer-run political implications of the crisis and broader socio-political dynamics shaping federal relations in each jurisdiction. They consider, for example, whether the crisis resulted in increased intergovernmental tensions and/or centralization and how these processes have varied across federations; how crisis-induced pressures may have impacted on the normative or political foundations of federal settlements; and what impacts broader social and political developments, in the form of new agendas and actors (political parties and movements) flowing from the consequences of the crisis, may have on the practice of federalism. An analysis of these questions can help establish the foundation for prospective analysis of the longer-term consequences of the crisis for the practice of federalism in the twenty-first century. The detailed case study analysis is followed by a theoretically informed yet empirically grounded assessment of the future of federalism in the twenty-first century.

\section{PLAN FOR THE STUDY}

Chapter 1 provides an empirical and theoretical context for the detailed case study analyses that follow. It first sets out data on both the macroeconomic impact of the crisis and the associated implications for public finances, in order to highlight the significant variation in impact across the jurisdictions reviewed in the case studies. This overview of the changing economic and fiscal context in which federal governance has occurred in recent years sets the stage for a summary of the relevant theoretical explanations of change in federal systems and a consideration of the extent to which recent developments in institutional theory can provide significant insights into the complex dynamics of change in federal regimes. As noted above, this scholarship will be used to frame the subsequent case study analysis.

Part II of the study (Chapters 2-5) focuses on the changing nature of federalism across the Anglosphere from the seminal example of the United States to the long-established colonial cases of Canada and Australia. 
Significantly, given the rise of the Scottish National Party and the increasingly federal character of the UK, the volume also includes detailed analysis of recent pressures driving federalization in the UK.

Paul Posner and Timothy Conlan, in their analysis of the impact of the financial crisis on federalism in the USA (Chapter 2), direct their attention to the weak institutionalization of intergovernmental fiscal collaboration. They argue that federal-state collaboration is opportunistic and ill-equipped to deal with imminent pressures caused by an ageing population and rising health-care costs. North of the border, Canada's provinces retain more fiscal independence than subnational governments in the majority of our case study countries. Douglas Brown (Chapter 3) finds that while this meant that the provinces shouldered the burden of austerity during the financial crisis, the intergovernmental response was characterized by cooperation rather than conflict. As a result, Canada's federal order can be characterized more by stability than change.

Richard Eccleston and Richard Krever (Chapter 4) contradict perceptions in some quarters that Australian federalism is stable and largely immune from the consequences of the financial crisis. Reflecting the volume's overall theme, they argue that slower post-crisis growth and unprecedented variation in economic performance across the federation has led to unprecedented interstate conflict and undermined the legitimacy of Australia's horizontal equalization regime. While these tensions give rise to pressure for fundamental reform, in the absence of political leadership the future of Australian federalism remains uncertain.

In perhaps the most dynamic case of the volume, Simon Lee (Chapter 5) finds considerable cause for pessimism regarding UK fiscal policy in the context of uncertainty regarding Scottish independence, increasing Welsh autonomy, and local government funding cuts. He argues that in combination with a public backlash against a wide-ranging austerity programme, these developments constitute an imminent threat to the British fiscal compact.

Part III (Chapters 6-9) of the volume examines the key trends in four significant continental European federations. This part starkly demonstrates the contrasting dynamics evident across federal regimes. In Germany and Switzerland, where the fiscal impact of the 2008 financial crisis was relatively moderate, incremental reform has been the order of the day. In contrast, the crisis and its aftermath have had profound consequences with far-reaching implications for intergovernmental relations in Italy and Spain.

Germany's current framework for intergovernmental relations expires in 2019 , meaning that in the coming years its fiscal compact will be renegotiated. Jan Schnellenbach (Chapter 6) discusses how these negotiations will 
no doubt be influenced by Germany's (relatively mild) crisis experience, and canvasses the possibilities for centralization or de-solidarization that the upcoming talks hold. In Switzerland, the effect of the financial crisis was limited to a brief downturn in 2009. However, Nils Soguel (Chapter 7) argues that the lack of horizontal (as between cantons) and vertical (between the central government and the cantons) cooperation in response to the crisis has resulted in a weakened fiscal structural balance, meaning that coordination in future crisis situations may be even harder to achieve.

In contrast to Germany and Switzerland, over the past decade Spain has suffered the most severe economic downturn of all our selected case studies, and César Colino and Eloísa del Pino (Chapter 8) discuss the impact of this on the Spanish Estado Autonómico. They argue that centralization and reduced fiscal autonomy among subnational governments is already occurring on the Iberian Peninsula, which in turn is fuelling the Catalan independence movement and threatening the Spanish Union. Similar economic impacts have led to vastly different pressures in Italy, Emanuele Massetti argues (Chapter 9), where the crisis has precipitated a push for greater political centralization in the Italian republic, which in part is driven by the Northern League's desire to become a national political movement.

Part IV (Chapters 10-13) of the volume represents an innovation in federalism research in that it extends the case analysis to four large emerging economies, each with elements of federal governance. This analysis is significant both because the impact of the crisis was initially less severe in emerging markets and because the influence of each of these states is likely to increase over the course of the twenty-first century.

Christine Wong's study (Chapter 10) of the Chinese response to the financial crisis questions the basis of China's ostensibly strong and effective stimulus programme. Her analysis suggests that the prominent role of local governments in the recovery effort undermined the central government's control, and has consequently brought the Chinese intergovernmental system to breaking point. Raghbendra Jha (Chapter 11) addresses three key questions in his analysis of how India's federal order could change post-crisis: how could fiscal relations between the central government and the states be reorganized to improve economic growth? How should the system of federal-state transfers be altered to return to the pre-crisis path of fiscal surpluses? And how can indirect tax reform contribute to these efforts?

José Roberto Afonso and Luiz de Mello (Chapter 12) examine the intriguing case of Brazil, which after initially experiencing a milder economic downturn than most of the cases presented in this collection has been grappling with a significant downturn since 2015. Their analysis 
focuses on how the different levels of government contributed to postcrisis fiscal adjustment and what impact the specific characteristics of Brazilian federalism will have on intergovernmental fiscal relations into the future. Ramos Mabugu (Chapter 13) demonstrates that South Africa, like Brazil, may be experiencing a more delayed impact from the financial crisis than the other case study states. He suggests that the central government's desire to reduce medium-term expenditure to address its increasing deficit is likely to become a source of tension in intergovernmental relations. The long-term impact of the crisis on South African federalism will thus largely depend on the magnitude, length and political sustainability of its fiscal consolidation.

\section{NOTES}

1. The majority of the international political economy literature has highlighted the surprising durability of the prevailing neo-liberal order (for example: Crouch, 2011; Blyth, 2013), while institutionalist scholars have highlighted the incremental nature of political reform since 2008 (Moschella and Tsingou, 2013).

2. Such a definition might include jurisdictions in which constituent governmental units have real practical political and fiscal autonomy but without formal constitutional sharing of sovereignty between tiers of government. While this deviates from the formal definition of federalism advanced by Riker (1975; see also Hueglin and Fenna, 2006, pp. 32-3), we believe that comparing change in both formal federations and 'quasi-federal' states adds depth to the analysis.

3. See also Ahmad, Bordignon and Brosio (2016) for a preliminary assessment of these issues in the context of the European Union (EU).

\section{REFERENCES}

Ahmad, Ehtisham, Massimo Bordignon and Giorgio Brosio (eds) (2016), Multi-Level Finance and the Euro Crisis: Causes and Effects, Cheltenham, UK and Northampton, MA: Edward Elgar.

Bednar, Jenna (2011), 'The political science of federalism', Annual Review of Law and Social Science, 7, 269-88.

Bell, Stephen and Andrew Hindmoor (2015), Masters of the Universe, Slaves of the Market, Cambridge, MA: Harvard University Press.

Benz, Arthur and Jörg Broschek (2013), 'Federal dynamics: introduction', in Arthur Benz and Jörg Broschek (eds), Federal Dynamics: Continuity, Change and the Varieties of Federalism, Oxford: Oxford University Press, pp. 1-23.

Blyth, Mark (2013), Austerity: The History of a Dangerous Idea, New York: Oxford University Press.

Braun, Dietmar and Philipp Trein (2014), 'Federal dynamics in times of economic and financial crisis', European Journal of Political Research, 53 (4), 803-21.

Campbell, John (2004), Institutional Change and Globalization, Princeton: Princeton University Press. 
Colino, César (2010), 'Understanding federal change: types of federalism and institutional evolution in the Spanish and German federal systems', in Jan Erk and Wilfried Swenden (eds), New Directions in Federalism Studies, London: Routledge, pp. 16-33.

Colino, César and Eloísa del Pino (2014), 'Spanish federalism in crisis', in Paul E. Peterson and Daniel Nadler (eds), The Global Debt Crisis: Haunting U.S. and European Federalism, Washington: Brookings Institution Press, pp. 159-78.

Crouch, Colin (2011), The Strange Non-Death of Neo-Liberalism, Cambridge: Polity Press.

Eccleston, Richard (2007), Taxing Reforms: The Politics of the Consumption Tax in Japan, the United States, Canada and Australia, Cheltenham, UK and Northampton, MA: Edward Elgar.

Erk, Jan (2008), Explaining Federalism: State, Society and Congruence in Austria, Belgium, Canada, Germany, and Switzerland, London: Routledge.

Erk, Jan and Wilfried Swenden (2010), 'The new wave of federalism studies', in Jan Erk and Wilfried Swenden (eds), New Directions in Federalism Studies, London: Routledge and the European Consortium for Political Research, pp. 1-15.

Gerring, John and Rose McDermott (2007), 'An experimental template for case study research', American Journal of Political Science, 51 (3), 688-701.

Grant, Wyn and Graham Wilson (eds) (2012), The Consequences of the Global Financial Crisis: The Rhetoric of Reform and Regulation, Oxford: Oxford University Press.

Hay, Colin (2002), Political Analysis: A Critical Introduction, Hampshire: Palgrave Macmillan.

Helleiner, Eric (2014), The Status Quo Crisis: Global Financial Governance After the 2008 Meltdown, Oxford: Oxford University Press.

Hueglin, Thomas O. and Alan Fenna (2006), Comparative Federalism: A Systematic Inquiry, Peterborough: Broadview Press.

Kay, Adrian (2006), The Dynamics of Public Policy: Theory and Evidence, Cheltenham, UK and Northampton, MA: Edward Elgar.

Kincaid, John, G. Alan Tarr and Sonja Wälti (2010), 'Federalism and the global financial crisis: impacts and responses - introduction', L'Europe En Formation, 4 (358), 5-14.

King, Gary, Robert Keohane and Sidney Verba (1994), Designing Social Inquiry, Princeton: Princeton University Press.

Mahoney, James and Kathleen Thelen (2010), 'A theory of gradual institutional change', in James Mahoney and Kathleen Thelen (eds), Explaining Institutional Change: Ambiguity, Agency, and Power, Cambridge: Cambridge University Press, pp. 1-37.

Moschella, Manuela and Eleni Tsingou (eds) (2013), Great Expectations, Slow Transformations: Incremental Change in Post-Crisis Regulation, Colchester: ECPR Press.

Oates, Wallace (1972), Fiscal Federalism, New York: Harcourt Brace Jovanovich.

Obinger, Herbert, Stephan Leibfried and Francis G. Castles (eds) (2005), Federalism and the Welfare State: New World and European Experiences, Cambridge: Cambridge University Press.

Oliver, Michael and Hugh Pemberton (2004), 'Learning and change in 20th century British economic policy', Governance, 17 (3), 415-41. 
Olson, Mancur (1965), The Logic of Collective Action, Cambridge, MA: Harvard University Press.

Pierson, Paul (2004), Politics in Time, Princeton: Princeton University Press.

Riker, William H. (1975), 'Federalism', in Fred I. Greenstein and Nelson W. Polsby (eds), The Handbook of Political Science, Vol. 5: Governmental Institutions and Processes, Reading, MA: Addison-Wesley, pp. 93-172.

Scharpf, Fritz (1988), 'The joint-decision trap: lessons from German Federation and European integration', Public Administration, 66 (3), 239-78.

Simeon, Richard and Daniel-Patrick Conway (2001), 'Federalism and the management of conflict in multinational societies', in Alain-G. Gagnon and James Tully, Multinational Democracies, Cambridge: Cambridge University Press, pp. 338-65.

Streeck, Wolfgang and Kathleen Thelen (2005), 'Introduction: institutional change in advanced political economies', in Wolfgang Streeck and Kathleen Thelen (eds), Beyond Continuity: Institutional Change in Advanced Political Economies, New York: Oxford University Press, pp. 1-39.

Wibbels, Erik (2000), 'Federalism and the politics of macroeconomic policy and performance', American Journal of Political Science, 44 (4), 687-702. 